\title{
Killing of spores of Bacillus subtilis by peroxynitrite appears to be caused by membrane damage
}

\author{
Peter C. Genest, Barbara Setlow, Elizabeth Melly and Peter Setlow
}

Author for correspondence: Peter Setlow. Tel: +1 860679 2607. Fax: +1 860679340.

e-mail: setlow@sun.uchc.edu

Department of Biochemistry, University of Connecticut Health Center, Farmington, CT 06032, USA

\begin{abstract}
During an infection of a higher eukaryote, dormant spores of a Bacillus species have been previously shown to be present in cells that can generate the toxic agent peroxynitrite (PON). Dormant spores of Bacillus subtilis were much more resistant to killing by PON than were growing cells, and spore-coat alteration or removal greatly decreased PON resistance. Spores were not killed by PON through DNA damage and lost no dipicolinic acid (DPA) during PON treatment. However, PON-killed spores lost DPA during subsequent heat treatments that caused much less DPA release from untreated spores. Although dead, the PONkilled spores germinated and initiated metabolism but never went through outgrowth; the great majority of germinated PON-killed spores also took up propidium iodide, indicating that they had suffered significant membrane damage and were dead. Together these data suggest that spore killing by PON is through some type of damage to the spore's inner membrane.
\end{abstract}

Keywords: spore resistance, spore killing, membrane damage

\section{INTRODUCTION}

Among the many human defences against bacteria is the generation of reactive oxygen species by a number of cell types, most notably phagocytes. Whilst a variety of reactive oxygen species are generated by these cells, production of the superoxide anion is most notable as this compound can react with nitric oxide to form the peroxynitrite (PON) anion, an extremely reactive nitrogen species (Hozz et al., 1992; Beckman \& Koppenol, 1996). PON can react with proteins to cause oxidation of sulfur-containing amino acids and iron-sulfur centres as well as nitration of tyrosine residues, and can also cause a variety of types of damage to DNA and lipids, because PON is a strong oxidant (Beckman \& Koppenol, 1996; Keyer \& Imlay, 1997; Perrin \& Koppenol, 2000). A number of studies have shown that PON can kill and mutagenize growing bacteria (Brunnelli et al., 1995; Hurst \& Lymar, 1997; Kuwahara et al., 2000; Routledge, 2000). However, no such studies have been carried out with bacterial endospores, which are generally much more resistant than growing bacteria to toxic chemicals (Russell, 1982, 1990; Bloomfield \& Arthur, 1994; McDonnell \& Russell, 1999; Setlow, 2000). Another reason for analysis of the effect of PON

Abbreviations: DPA, dipicolinic acid; PON, peroxynitrite; SASP, small acid-soluble protein. on spores is recent work showing that a major route for infection with spores of a human pathogen, Bacillus anthracis, is via uptake and subsequent germination of spores of this organism within alveolar macrophages, cells which can generate PON (Guidi-Rontani et al., 1999). Consequently, we have undertaken a study of the mechanism of spore resistance to and killing by PON using the model spore-forming organism Bacillus subtilis.

\section{METHODS}

Bacterial strains, and isolation of spores and growing cells. The $B$. subtilis strains used were all derivatives of strain 168 (originally obtained from D. J. Tipper, University of Massachusetts Medical School, Worcester, MA, USA), and all contained drug-resistance markers to facilitate accurate identification of survivors of spore-killing experiments. Strain PS533 carries plasmid pUB110 which also carries a kanamycinresistance marker, and strain PS578 (termed $\alpha^{-} \beta^{-}$) is isogenic with PS533, but lacks the genes encoding the spore's two major DNA-protective, small, acid-soluble spore proteins (SASPs) $\alpha$ and $\beta$ (Setlow \& Setlow, 1996; Setlow, 2000). Strain PS3328 has been described previously (Loshon et al., 2001) and is isogenic with strain PS533 but lacks pUB110 and contains a deletion of most of the $\cot E$ gene whose product is involved in spore-coat assembly and maturation (Driks, 1999; Driks \& Setlow, 1999). In strain PS3328, the $\cot E$ gene is replaced with a tetracycline-resistance marker (Loshon et al., 2001). Chromosomal DNA from strain PS3328 was used to transform strains 
PS533 and PS578 to tetracycline resistance, giving strains PS3394 (cotE pUB110) and PS3395 ( $\alpha^{-} \beta^{-} \operatorname{cotE}$ pUB110). Strains PS2318 and PS2319 are isogenic derivatives of PS533 and PS578, respectively, which lack plasmid pUB110, have also lost their recA gene encoding a protein responsible for much DNA repair in this organism and carry a chloramphenicolresistance marker (Yasbin et al., 1993; Setlow \& Setlow, 1996). Strain PS3388 is isogenic with strain PS578 but lacks plasmid pUB110 and carries an erythromycin-resistance marker as well as the luxAB genes from Vibrio harveyi under control of the strong $B$. subtilis forespore-specific sspB promoter (Hill et al., 1994). Spores of strain PS3388 accumulate the lux $A B$ gene products in dormant spores, but only generate light using these proteins during spore germination when metabolism begins (Hill et al., 1994; Ciarciaglini et al., 2000; Setlow et al., 2001). Spores of all these strains were prepared by growth at $37^{\circ} \mathrm{C}$ on $2 \times \mathrm{SG}$ medium plates without antibiotics, and spores were harvested, purified and stored as described (Nicholson \& Setlow, 1990; Paidhungat et al., 2000). All spore preparations used were free $(>97 \%)$ of growing or sporulating cells or germinated spores. Cells growing at $37^{\circ} \mathrm{C}$ in $2 \times$ YT medium (Loshon et al., 2001) were harvested at an $\mathrm{OD}_{600}$ of 1 , washed with $25 \mathrm{mmol}$ potassium phosphate $1^{-1}(\mathrm{pH} 7 \cdot 0)$ and resuspended in this buffer at an $\mathrm{OD}_{600}$ of 4 immediately prior to PON treatment.

PON synthesis and treatment of cells or spores. PON was synthesized by rapid mixing of $10 \mathrm{ml}$ ice-cold $250 \mathrm{mM}$ sodium nitrite and $270 \mu \mathrm{l} 22 \%$ hydrogen peroxide followed by rapid addition of $5 \mathrm{ml}$ ice-cold $1 \mathrm{~mol} \mathrm{HCl} \mathrm{l}^{-1}$ and $5 \mathrm{ml} 1.5 \mathrm{~mol}$ $\mathrm{NaOH} ~^{-1}$. Unreacted hydrogen peroxide was removed and the PON was stored as described (Beckman et al., 1994). PON concentrations were determined immediately prior to use by measurement of the $\mathrm{OD}_{302}$ of appropriate dilutions in $1.2 \mathrm{M}$ $\mathrm{NaOH}$ (Beckman et al., 1994).

Spores and growing cells were incubated with PON at an

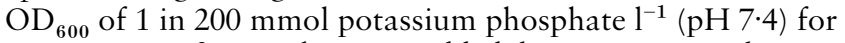
15 min at $24^{\circ} \mathrm{C}$, with PON added last. For control incubations, PON was diluted into the buffer prior to addition of spores or growing cells, the mix incubated for $15 \mathrm{~min}$ at $24^{\circ} \mathrm{C}$ to allow PON breakdown, spores or growing cells added, and the mix incubated a further $15 \mathrm{~min}$ at $24{ }^{\circ} \mathrm{C}$. Aliquots of PONtreated or control mixtures were diluted into phosphatebuffered saline $\left(0 \cdot 2 \mathrm{~g} \mathrm{KCl} \mathrm{l}^{-1}, 0 \cdot 24 \mathrm{~g} \mathrm{KH}_{2} \mathrm{PO}_{4} \mathrm{l}^{-1}, 8 \mathrm{~g} \mathrm{NaCl} \mathrm{l}{ }^{-1}\right.$, $1.44 \mathrm{~g} \mathrm{Na}_{2} \mathrm{HPO}_{4} \mathrm{l}^{-1}, \mathrm{pH} 7 \cdot 4$ ), appropriate dilutions plated on LB agar plates (Setlow \& Setlow, 1996) and colonies counted after $24-36 \mathrm{~h}$ incubation at $30-37^{\circ} \mathrm{C}$; incubation for longer times gave no increase in colonies. All killing experiments were repeated at least twice with two independent spore preparations, always with essentially identical results, as the slopes of killing curves for the same strain never varied by more than $25 \%$. However, in all experiments reported here, killing of spores of different strains was always carried out at the same time. In some experiments, catalase or pyruvate was added to the plates used for analysis of PON killing as described (Flowers et al., 1977; Hood et al., 1990).

The disinfectant Sterilox was prepared and analysed as described previously (Loshon et al., 2001); Sterilox preparations had $\mathrm{pH}$ values of $\sim 6.3$ and available free chlorine levels of $\sim 240 \mathrm{mg} \mathrm{l}^{-1}$. Spores were treated with Sterilox without prior decoating, the Sterilox inactivated and spores recovered and killing measured as described (Loshon et al., 2001).

Spore decoating, spore germination and analytical procedures. Spores were decoated by incubation for $30 \mathrm{~min}$ at $65^{\circ} \mathrm{C}$ in $100 \mathrm{mmol} \mathrm{NaOH} \mathrm{l}^{-1}, 100 \mathrm{mM} \mathrm{NaCl}, 5 \mathrm{~g} \mathrm{SDS} \mathrm{l}^{-1}$ and

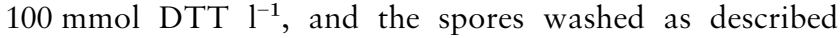
(Bagyan et al., 1998). Note that this decoating procedure also removes much, if not all, of the spore's outer membrane (Buchanan \& Neyman, 1986). Spores with or without PON treatment were tested for mutagenesis to asporogeny or auxotrophy as described by Fairhead et al. (1993). The pyridine-2,6-dicarboxylic acid [dipicolinic acid (DPA)] content of spores with or without PON treatment was assayed after DPA extraction by boiling as described (Rotman \& Fields, 1967; Nicholson \& Setlow, 1990). Spores with or without prior PON or Sterilox treatment were incubated in water at an $\mathrm{OD}_{600}$ of 5-9 for $30 \mathrm{~min}$ at various temperatures, cooled on ice for $10 \mathrm{~min}$, centrifuged in a microcentrifuge and DPA in the supernatant fluid assayed directly.

After a heat shock for $30 \mathrm{~min}$ at $70{ }^{\circ} \mathrm{C}$ in water, spores were germinated at an $\mathrm{OD}_{600}$ of 1 in either $2 \times$ YT medium (Setlow \& Setlow, 1996) plus $4 \mathrm{mmol} \mathrm{L-alanine} \mathrm{l}^{-1}$ or $10 \mathrm{mmol}$ Tris $/ \mathrm{HCl}^{-1}\left(\mathrm{pH} 8 \cdot 3\right.$ ) plus $8 \mathrm{mmol} \mathrm{L}$-alanine $\mathrm{l}^{-1}$. DPA release, hexosamine release from spore cortex peptidoglycan and the percentage of spores that had turned phase dark or swelled were determined as described (Popham et al., 1996; Loshon et al., 2001). For analysis of light production during germination of spores carrying the $V$. harveyi lux $A B$ genes, spores were germinated in $2 \times$ YT medium plus L-alanine as described above; at various times aliquots of $500 \mu \mathrm{l}$ were mixed with 500 $\mu \mathrm{l}$ fresh medium and dodecanal added to $0 \cdot 1 \mathrm{~g} \mathrm{l}^{-1}$ as described (Hill et al., 1994; Loshon et al., 2001). Light production was measured in a Turner TD-20/20 Luminometer over three consecutive intervals of $10 \mathrm{~s}$ and values extrapolated to the time of dodecanal addition, since light production from the $V$. harveyi LuxA and B gene products in B. subtilis decays, as seen previously (Karp, 1989; Ciarciaglini et al., 2000; Loshon et al., 2001). Recovery of decoated spores by treatment with lysozyme in a hypertonic medium was as described by Popham et al. (1996). Spores were stained with acridine orange and examined by fluorescence microscopy as described by Setlow et al. (2001).

\section{RESULTS}

In preliminary experiments we found that incubation of spores with 5 mmol 3-morpholinosydnonimine- $N$-ethylcarbamide (SIN-1) $\mathrm{l}^{-1}$, a compound which decomposes slowly to superoxide and nitric oxide, generating low levels of PON (Beckman \& Koppenol, 1996), gave no killing of intact or decoated B. subtilis spores (data not shown). Since $5 \mathrm{mmol} \mathrm{SIN-1} \mathrm{l}^{-1}$ is very rapidly lethal to growing bacteria (Brunelli et al., 1995), it appeared that spores were not particularly sensitive to PON and that we would have to use high concentrations of this agent to get spore killing. Indeed, incubation with up to $16 \mathrm{mmol} \mathrm{PON}^{-1}$ gave no $(<15 \%)$ detectable killing of intact dormant $B$. subtilis spores of either wild-type (PS533) or $\alpha^{-} \beta^{-}$(PS578) strains (Fig. 1a). In contrast, germinated wild-type and $\alpha^{-} \beta^{-}$spores were readily killed by PON and growing wild-type and $\alpha^{-} \beta^{-}$cells were even more PON sensitive (Fig. 1a and data not shown). A major factor in spore PON resistance was the spore-coat structure, as PON resistance of either wild-type or $\alpha^{-} \beta^{-}$ spores was greatly decreased by removal of much coat protein by a decoating regimen (Fig. 1a, b). Similarly, a $\cot E$ mutation that disrupts spore-coat assembly as well as much coat maturation (Driks, 1999; Driks \& Setlow, 1999) also decreased spore PON resistance greatly (Fig. 
(a)

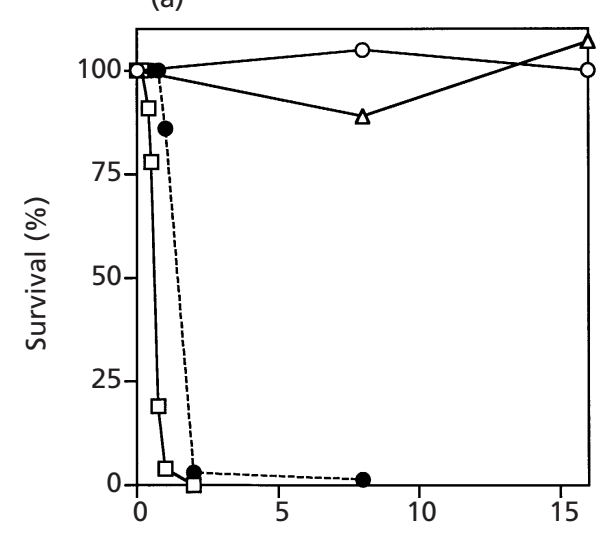

(b)

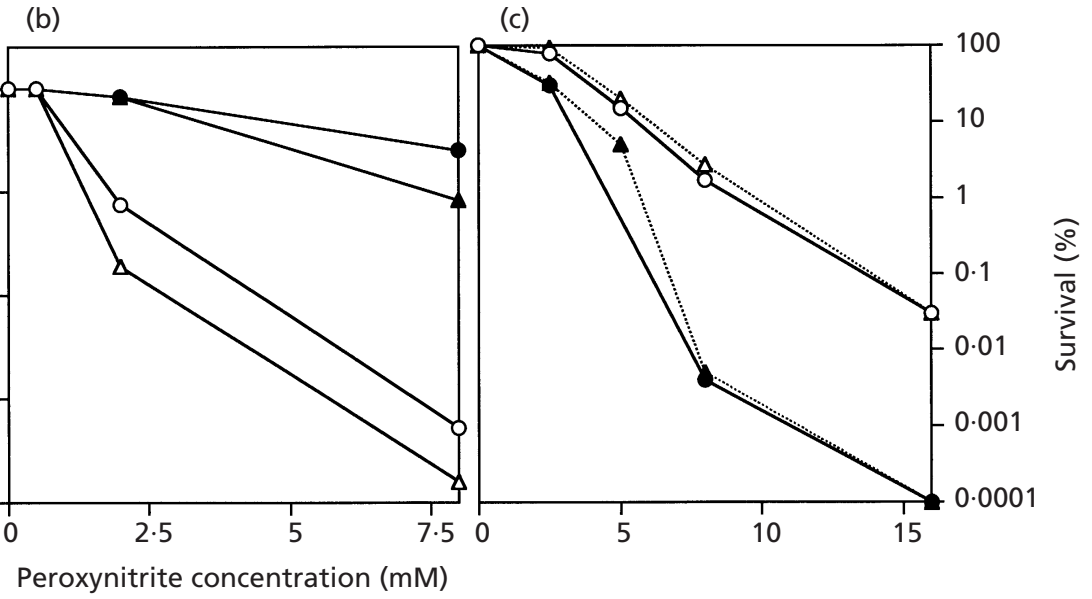

Fig. 1. Killing of dormant and germinated spores and growing cells of $B$. subtilis strains by PON. Intact dormant or germinated spores or growing cells (a); decoated dormant spores (b); or intact or decoated cotE spores (c) of $B$. subtilis were treated with various concentrations of PON and survival measured as described in Methods. The symbols used are: (a) $\bigcirc$, intact wild-type spores (PS533); $\triangle$, intact $\alpha^{-} \beta^{-}$spores (PS578);, , germinated (3 h in Tris/alanine) wild-type spores (PS533); $\square$, growing wild-type cells (PS533); (b) $\bigcirc$, decoated wild-type spores (PS533); $\triangle$, decoated $\alpha^{-} \beta^{-}$spores (PS578); $\boldsymbol{0}$, decoated recA spores (PS2318); $\boldsymbol{\Delta}$, decoated $\alpha^{-} \beta^{-}$recA spores (PS2319); and (c) $O$, intact cotE spores (PS3394); $\triangle$, intact $\alpha^{-} \beta^{-}$cotE spores (PS3395); $\boldsymbol{0}$, decoated cotE spores (PS3394); and $\boldsymbol{\Delta}$, decoated $\alpha^{-} \beta^{-} \cot E$ spores (PS3395). Note that (a) and (b) have the same scales on their vertical axes.

Table 1. Killing and mutagenesis of spores with PON

Spores with or without PON treatment were analysed for mutation to asporogeny (spo), auxotrophy (aux) or both (aux spo) as described in the text.

\begin{tabular}{|c|c|c|c|c|c|c|c|}
\hline \multicolumn{2}{|c|}{ Mutations } & \multirow[t]{2}{*}{ Survival (\%) } & \multirow[t]{2}{*}{ Total tested } & \multirow[t]{2}{*}{$a u x$} & \multirow[t]{2}{*}{ spo } & \multirow[t]{2}{*}{ aux spo } & \multirow[t]{2}{*}{$\%$} \\
\hline Spores & Treatment & & & & & & \\
\hline Wild-type (PS533) & None & 100 & 475 & 0 & 0 & 0 & 0 \\
\hline Wild-type (PS533) & $8 \mathrm{mmol} \mathrm{PON} \mathrm{l}^{-1}$ & 22 & 689 & 0 & 0 & 0 & 0 \\
\hline$\alpha^{-} \beta^{-}(\mathrm{PS} 578)$ & None & 100 & 727 & 4 & 3 & 0 & 1 \\
\hline$\alpha^{-} \beta^{-}$(PS578) & $8 \mathrm{mmol} \mathrm{PON} \mathrm{l}^{-1}$ & 6 & 533 & 3 & 2 & 0 & 1 \\
\hline
\end{tabular}

1a, c). However, even the decoated $\cot E$ spores were more PON resistant than were growing cells (Fig. 1a, c). There was only a slight difference in the PON resistance of decoated spores of wild-type or $\alpha^{-} \beta^{-}$strains (Fig. 1b) and even this slight difference was not observed with intact or decoated $\cot E$ or $\alpha^{-} \beta^{-} \cot E$ spores (Fig. 1c).

SASP $-\alpha$ and $\beta$ protect spore DNA from many types of damage (Setlow, 2000), so the observation that wildtype and $\alpha^{-} \beta^{-}$spores exhibited generally similar PON resistance suggested that PON killing of spores was not through DNA damage. Indeed, there was no increase in mutations in the survivors of PON treatment of wildtype or $\alpha^{-} \beta^{-}$spores, although the untreated $\alpha^{-} \beta^{-}$spores did have a significant level of mutations undoubtedly acquired during sporulation, spore purification and storage, as seen previously (Table 1) (Fairhead et al., 1993; Loshon et al., 2001). That spore killing by PON was not through DNA damage was further indicated by the lack of sensitization of spores to PON by a mutation in the recA gene which abolishes repair of a number of types of DNA damage during spore germination and outgrowth (Fig. 1b) (Yasbin et al., 1993; Setlow \& Setlow 1996). A recA mutation actually sensitizes spores to agents that kill spores through damage to spore DNA (Setlow \& Setlow, 1996). Decoated spores of the recA derivatives were actually more PON resistant than their counterparts with a wild-type $\operatorname{rec} A$ gene (Fig. 1b). The reason for the higher $\mathrm{PON}$ resistance of recA spores is not clear, but this has been seen previously for a number of chemicals that do not kill spores by DNA damage, and has been suggested to be due to significant differences in the sporulation of wild-type and recA strains which in turn causes significant differences in the properties of the resultant spores (Tennen et al., 2000; Loshon et al., 2001). The slightly decreased PON resistance of decoated $\alpha^{-} \beta^{-}$spores relative to that of decoated wild-type spores (Fig. 1b) may also be due to slight differences in the sporulation of wild-type and $\alpha^{-} \beta^{-}$strains causing differences in the properties of the 
Table 2. DPA release from PON- or Sterilox-killed spores

Spores of strains PS533 or PS578 were either not treated, or treated with PON or Sterilox with (PON treatment) or without (Sterilox treatment) prior decoating, and spore killing and subsequent DPA release after various treatments analysed as described in Methods.

\begin{tabular}{|c|c|c|c|c|}
\hline \multirow[t]{2}{*}{ Treatment } & \multirow[t]{2}{*}{ Survival (\%) } & \multicolumn{3}{|c|}{ DPA release $(\%)$} \\
\hline & & $\begin{array}{l}\text { No further } \\
\text { treatment }\end{array}$ & $30 \mathrm{~min}, 80^{\circ} \mathrm{C}$ & $30 \mathrm{~min}, 85^{\circ} \mathrm{C}$ \\
\hline Decoated $*$ & $>90$ & $<5$ & 5 & 8 \\
\hline PON* & 1 & $<5$ & 17 & 57 \\
\hline None† & 100 & $<3$ & 4 & 6 \\
\hline Sterilox $†$ & 5 & $<5$ & 15 & 31 \\
\hline
\end{tabular}

* PS578 spores.

†PS533 spores.

Table 3. Analysis of germinated PON- and control PON-treated spores

Spores of strain PS578 $\left(\alpha^{-} \beta^{-}\right)$were decoated, and either not treated, control PON treated or PON treated; spore killing was determined as described in Methods, as were DPA and hexosamine release upon spore germination and germinated spore viability.

\begin{tabular}{|c|c|c|c|}
\hline & $\begin{array}{l}\text { PON-treated } \\
\text { (\% killing) }\end{array}$ & Control-treated $*$ & Decoated" \\
\hline $\begin{array}{l}\text { DPA release upon spore germination } \\
(\% \text { of total }) \dagger\end{array}$ & $89(96)$ & 92 & 93 \\
\hline $\begin{array}{l}\text { Hexosamine release upon spore } \\
\text { germination }(\% \text { of total }) \neq\end{array}$ & $3(95)$ & 5 & 25 \\
\hline Viability of germinated spores $(\%)+\$$ & $8(94)$ & 97 & 96 \\
\hline
\end{tabular}

* There was $<10 \%$ spore killing by decoating with or without the control treatment.

† Spores were germinated for $2 \mathrm{~h}$ in $2 \times \mathrm{YT}$ medium.

$\neq$ Spores were germinated for $3 \mathrm{~h}$ in Tris/alanine.

$\$$ Germinated spore viability measured using the BacLite viability stain (Molecular Probes).

spores produced, as suggested previously (Setlow et al., 2000; Tennen et al., 2000; Loshon et al., 2001). However, these differences are not evident in intact or decoated spores of $\cot E$ strains (Fig. 1c).

The data given above indicate that spores are not killed by PON through DNA damage and this prompted us to look at other mechanisms of spore killing. Most of this work was carried out with spores of strain PS578 because of the slightly greater PON sensitivity of the decoated spores of this strain, but results with spores of strain PS533 were similar where examined (data not shown). Initially we examined the disruption of the spore's inner-membrane permeability barrier, as this can accompany spore killing by wet heat (Russell, 1982). However, analysis of decoated dormant spores killed by PON indicated that the major small molecule found in the spore core, DPA, was not released by PON treatment (Table 2). Thus PON killing of spores is not through a severe disruption of the dormant spore's inner mem- brane. However, this latter permeability barrier appeared to be at least slightly damaged by PON treatment, as PON-killed spores released much more DPA upon subsequent heat treatment than did untreated spores (Table 2). Interestingly, spore killing by the disinfectant Sterilox (Selkon et al., 1999; Shetty et al., 1999; Middleton et al., 2000; Loshon et al., 2001) also resulted in DPA release upon subsequent heat treatment (Table 2), although Sterilox killing alone again resulted in no DPA release, as shown previously (Table 2).

A third possible mechanism for spore killing is by inactivation of one or more components of the spore germination apparatus and several chemicals have been shown to kill spores at least in part by this mechanism (Williams \& Russell, 1993a, b; Tennen et al., 2000). However, PON-killed spores did release their DPA upon incubation of spores with germinants (Table 3). PONkilled spores also became dark in the phase-contrast microscope upon spore germination, and at a rate only 


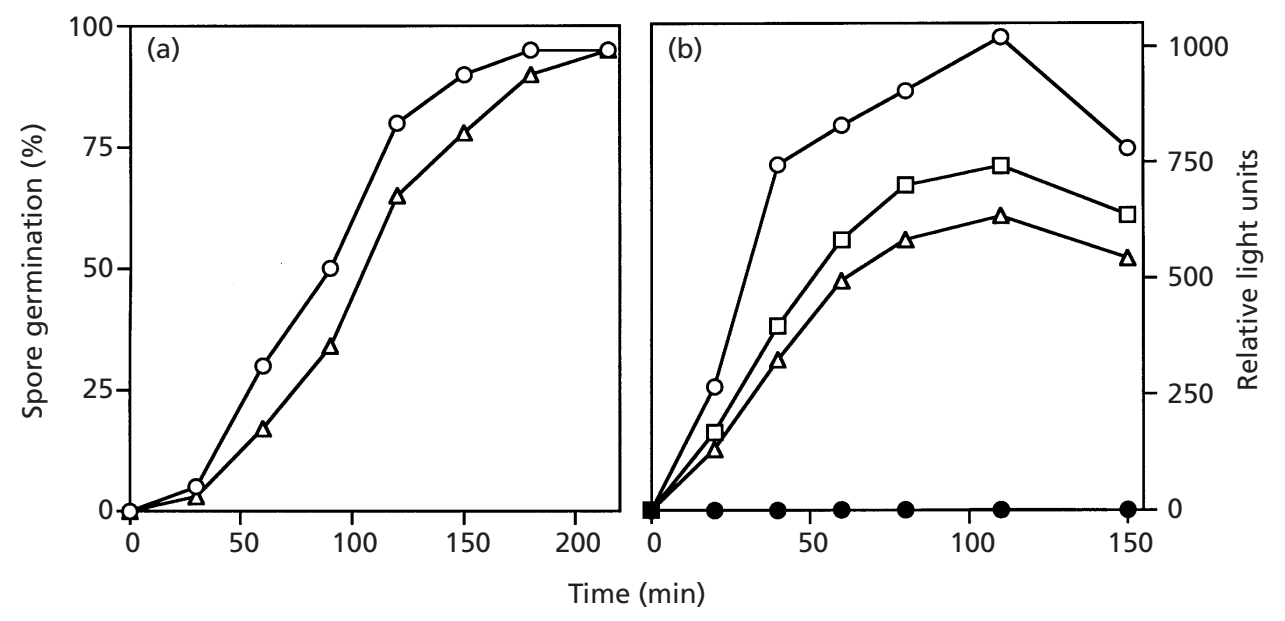

Fig. 2. Germination of and light production from PON- and control PON-treated spores. (a) Decoated spores of strain PS578 $\left(\alpha^{-} \beta^{-}\right)$either control PON-treated or treated with $8 \mathrm{mmol}$ PON I-1 were germinated in Tris/HCl plus L-alanine as described in Methods. At various times $\geqslant 100$ spores were examined under the phase-contrast microscope and the percentage of phase-dark spores determined as a measure of spore germination. (b) Decoated spores of strain PS3388 $\left(\alpha^{-} \beta^{-}\right.$luxAB), either PON-treated or control PON-treated, or untreated intact spores of strain PS533 were germinated in $2 \times$ YT medium plus L-alanine and light production was measured after dodecanal addition at various times as described in Methods. The symbols used are: (a) $\bigcirc$, control PON-treated $\alpha^{-} \beta^{-}$spores (PS578); $\triangle, \alpha^{-} \beta^{-}$spores (PS578) treated with $8 \mathrm{mmol}$ PON I-1 giving $94 \%$ killing; (b) $\bullet$, untreated wild-type spores (PS533); $\bigcirc$, control PON-treated $\alpha^{-} \beta^{-}$luxAB spores (PS3388); $\square, \alpha^{-} \beta^{-}$luxAB spores (PS3388) treated with $5 \mathrm{mmol}$ PON ${ }^{-1}$ giving $64 \%$ killing; and $\triangle, \alpha^{-} \beta^{-}$luxAB spores (PS3388) treated with $8 \mathrm{mmol}$ PON $\mathrm{I}^{-1}$ giving $96 \%$ killing.

slightly slower than did control-treated spores (Fig. $2 \mathrm{a})$; the central regions or cores of PON-killed $(99 \%)$ $\alpha^{-} \beta^{-}$spores germinated for $215 \mathrm{~min}$ in Tris/alanine were also stained completely with the nucleic acid stain acridine orange which does not penetrate the core of dormant spores (data not shown). PON-killed spores initiated metabolism upon mixing of spores with germinant, as shown by measuring light production catalysed by the $V$. harveyi lux $A B$ gene products (Fig. 2b), as this process requires production of reduced flavin mononucleotide, which is absent from dormant spores (Karp, 1989; Hill et al., 1994; Setlow, 1994). Whilst there was slightly reduced light production from germinating PON-treated spores compared to that from control PON-treated spores, the reduction in light production was much, much less than the degree of spore killing (Fig. 2b) and light production in this assay is linear with the amount of untreated spores assayed (data not shown). All these data thus suggest that PONkilled spores can undergo the normal early events in the spore germination process (Paidhungat \& Setlow, 2001; Setlow et al., 2001). These events include the disruption of the peptidoglycan cortex that restricts the approximately twofold expansion of the spore core, an early germination event which is essential for initiation of spore metabolism and staining of the spore core by acridine orange (Setlow et al., 2001). Surprisingly, analysis of both PON- and control PON-treated spores indicated that significant amounts of cortex fragments, as measured by assays of hexosamine, were not released into the medium during germination of these spores, although decoated spores did release cortex fragments during germination (Table 3 ). However, the cortex must be disrupted during germination of PON- and control PON-treated spores since upon mixing with a germinant, both types of spores initiated metabolism, became dark under phase-contrast microscopy, stained fully with acridine orange, and colony formation by the control-treated spores was normal. Previous work has shown that cortex disruption during spore germination is necessary for all these latter events (Setlow et al., 2001). That a block in cortex disruption during germination is not the reason for PON killing of spores was shown further by the inability of lysozyme treatment in hypertonic medium to recover PON-killed spores (data not shown). This treatment has been shown previously to recover spores in which cortex disruption during spore germination is blocked (Popham et al., 1996; Setlow et al., 2001). Possibly some enzyme needed only for release of cortex fragments from spores but not for cortex disruption is inactivated by a PON breakdown product. PON-killed spores were also not recovered by addition of either catalase or pyruvate to the plating medium (data not shown). These additions have been shown to increase the recovery of Gram-positive bacteria subjected to a variety of harsh treatments, although the reasons for these effects are not known (Flowers et al., 1977; Hood et al., 1990).

Although PON-killed spores do initiate early events in spore germination, even in a rich medium the volume of the cores of these spores did not increase significantly $(<25 \%$ increase in spore diameter; data not shown) and the germinated spores never gave rise to colonies. Indeed, analysis of germinated spore viability using the BacLite stain from Molecular Probes as described by 
Murray et al. (1998) indicated that the great majority of PON-killed spores appeared dead in this assay as they took up propidium iodide, while $>90 \%$ of the controltreated spores were alive (Table 3). This latter finding was made previously in examining spores killed by Sterilox (Loshon et al., 2001).

\section{DISCUSSION}

There are two major but related questions arising from the results presented in this report: (i) what are the factors involved in the high resistance of spores to PON and (ii) what is the mechanism whereby spores are killed by PON? In examining factors involved in spore PON resistance, the spore coat clearly plays a major role, given the much greater PON sensitivity of decoated or $\cot E$ spores. The B. subtilis spore coat is exterior to the outer spore membrane, contains a large number of proteins and is important in spore resistance to both lysozyme and a number of chemicals (Russell, 1990; Bloomfield \& Arthur, 1994; Driks, 1999; Driks \& Setlow, 1999; Nicholson et al., 2000; Setlow, 2000). While the spore coat may provide lysozyme resistance simply by blocking the access of this enzyme to the peptidoglycan cortex, the precise mechanism whereby the spore coat protects against chemicals is not clear. The spore coat is thought to be permeable to small molecules such as PON and possibly the spore coat proteins provide a reactive barrier restricting access of the short-lived PON to more sensitive areas of the spore. The outer membrane could also restrict PON access to the spore's inner regions, although this structure may not be a complete membrane in the dormant spore (Driks \& Setlow, 1999). Indeed, since decoating of $\cot E$ spores had only a moderate effect on their PON resistance and decoating largely if not completely removes the spore's outer membrane (Buchanan \& Neyman, 1986), it appears most likely that the outer spore membrane plays no role in spore PON resistance.

While removal of much coat protein by either mutation or decoating greatly reduced spore PON resistance, decoated or cotE spores are much more PON resistant than are growing cells. Although the coat protein remaining in decoated or cotE spores could provide significant protection against PON, it seems more likely that there are factors in addition to the spore coat which are involved in spore PON resistance. Other factors that have been identified as involved in spore resistance to one or more chemicals include the relative impermeability of the spore's inner membrane, the dehydration and mineralization of the spore core, the protection of spore DNA from damage by its saturation with $\alpha / \beta$-type SASP, and the repair of damage, in particular to DNA, in the early minutes of spore germination (Setlow, 2000). Neither DNA repair nor the $\alpha / \beta$-type SASP appears to play any role in spore PON resistance, as PON treatment of neither wild-type nor $\alpha^{-} \beta^{-}$spores caused mutagenesis and a recA mutation did not decrease spore PON resistance. Since growing bacteria are mutagenized by PON and DNA repair is a crucial factor in their PON resistance (Routledge, 2000; Spek et al., 2001), these findings imply that PON causes no significant DNA damage in spores and thus that PON levels in the spore core, the site of spore DNA, must never become very high. Consequently, the dehydration and mineralization of the spore core, which probably reduce the rates of reactions of toxic chemicals with spore core targets (Setlow, 2000), may not be particularly important in spore PON resistance. This analysis thus suggests that a major factor in spore PON resistance may be the relative impermeability of the spore's inner membrane to PON. This latter compound is largely an anion at neutral $\mathrm{pH}$ and previous work has shown that charged molecules penetrate the spore core extremely poorly (Gerhardt et al., 1972; Khairutdinov et al., 2000). In contrast, the protonated form of $\mathrm{PON}$, peroxynitrous acid, is a neutral species which is thought to readily cross biological membranes (Khairutdinov et al., 2000), and the spore core is permeable to small uncharged molecules $<150 \mathrm{Da}$ in size (Gerhardt et al., 1972). However, the rate of permeation of small uncharged molecules, for example unprotonated methylamine, into the spore core is extremely slow, possibly because of the compressed state of the spore's inner membrane (Setlow \& Setlow, 1980; Driks \& Setlow, 1999). Consequently the slow permeation of peroxynitrous acid across the inner spore membrane may restrict most PON action to targets on the outer surface of or exterior to the spore's inner membrane. It might be expected that PON would be more effective in killing bacteria at lower $\mathrm{pH}$ values because the higher levels of the more permeable peroxynitrous acid at lower $\mathrm{pH}$ values would result in more PON inside cells. However, this has not been observed by others, perhaps due to the greater lability of peroxynitrous acid relative to PON (Hurst \& Lymar, 1997; Khairutdinov et al., 2000). It is also worth noting that enzymic detoxification of PON by reduction, a significant factor in the PON resistance of growing bacteria (Chen et al., 1998; Bryk et al., 2000), is almost certainly not important in spore PON resistance. Whilst at least one enzyme that is reported to detoxify PON, alkyl hydroperoxide reductase subunit $\mathrm{C}$, is present in the spore core, this enzyme as well as catalase has been shown to play no role in dormant spore resistance to peroxides, most likely because of the inactivity of enzymes in the dormant spore core (Casillas-Martinez \& Setlow, 1997; Chen et al., 1998).

A tentative conclusion from the material presented above is that spores are most likely killed by PON action on the outer surface of, or exterior to, the spore's inner membrane. This region of the spore contains the receptors for germinants as well as the enzymes that are involved in the depolymerization of the spore cortex (Paidhungat \& Setlow, 2001). However, spore germination is not abolished in PON-killed spores, as these spores release DPA and initiate metabolism upon mixing of spores with germinants. It is true that cortex fragments are not released into the medium during this latter process with PON-killed spores. However, the cortex of PON-killed germinated spores must be significantly depolymerized, since initiation of metabolism 
and complete staining of the germinated spore by acridine orange are observed, and both these processes have been shown to require cortex depolymerization (Setlow et al., 2001). However, whilst PON-killed spores do initiate germination, these germinated spores have severe permeability defects as shown by their uptake of propidium iodide, a hallmark of bacteria with a damaged cytoplasmic membrane; in germinated spores this latter membrane is derived from the spore's inner membrane. The precise nature of the inner membrane damage caused by PON is not clear, but PON is a strong oxidant and at concentrations well below those used in the current work can damage both membrane lipids and proteins (Soszynski \& Bartosz, 1996; Gadhela et al., 1997; Mallozzi et al., 1997). That PON-killed dormant spores have suffered some type of membrane damage is also suggested by their poor retention of DPA upon subsequent heat treatment. The precise barrier to DPA loss from dormant spores is not known, but a major role for the inner spore membrane in the process seems most likely. Therefore, a likely scenario for PON killing of $B$. subtilis spores is that this agent causes some type of damage to the spore's inner membrane that does not breach the permeability barrier of this membrane, perhaps because the inner membrane is extremely compressed in the dormant spore. However, the permeability barrier of this membrane is weakened by the PON damage, resulting in more rapid loss of DPA on spore heating. Upon spore germination and the inner membrane expansion to accommodate the rapid twofold expansion of the core's volume in the absence of membrane synthesis (Paidhungat \& Setlow, 2001), the effects of the inner-membrane damage caused by PON become much more severe, resulting in spore death even though early events in spore germination are relatively normal. Interestingly, essentially all the findings reported here on PON killing of B. subtilis spores are extremely similar to those made both previously and in the current work examining spore killing by the superoxidized water, Sterilox (Loshon et al., 2001). This suggests that both these agents kill $B$. subtilis spores by similar mechanisms, possibly through damage to the inner spore membrane as we suggest here. The challenge now is to identify and quantitate this membrane damage.

\section{ACKNOWLEDGEMENTS}

This work was supported by a grant from the Army Research Office.

\section{REFERENCES}

Bagyan, I., Noback, M., Bron, S., Paidhungat, M. \& Setlow, P. (1998). Characterization of $y h c N$, a new forespore-specific gene of Bacillus subtilis. Gene 212, 179-188.

Beckman, J. S. \& Koppenol, W. H. (1996). Nitric oxide, superoxide, and peroxynitrite: the good the bad and the ugly. Am J Physiol 271, C1424-C1437.

Beckman, J. S., Chen, J., Ischiropoulus, H. \& Crow, J. P. (1994). Oxidative chemistry of peroxynitrite. Methods Enzymol 233, 229-240.

Bloomfield, S. F. \& Arthur, M. (1994). Mechanisms of inactivation and resistance of spores to chemical biocides. J Appl Bacteriol 76, 91S-104S.

Brunnelli, L., Crow, J. P. \& Beckman, J. S. (1995). The comparative toxicity of nitric oxide and peroxynitrite to Escherichia coli. Arch Biochem Biophys 316, 327-334.

Bryk, R., Griffin, P. \& Nathan, C. (2000). Peroxynitrite reductase activity of bacterial peroxiredoxins. Nature 407, 205-211.

Buchanan, C. E. \& Neyman, S. L. (1986). Correlation of penicillinbinding protein composition with different functions of two membranes in Bacillus subtilis forespores. J Bacteriol 165, 498-503.

Casillas-Martinez, L. \& Setlow, P. (1997). Alkyl hydroperoxide reductase, catalase, $\mathrm{MrgA}$, and superoxide dismutase are not involved in resistance of Bacillus subtilis spores to heat or oxidizing agents. J Bacteriol 179, 7420-7425.

Chen, L., Xie, Q. \& Nathan, C. (1998). Alkyl hydroperoxide reductase subunit $\mathrm{C}(\mathrm{AhpC})$ protects bacterial and human cells against reactive nitrogen intermediates. Mol Cell 1, 795-805.

Ciarciaglini, G., Hill, P. J., Davies, K., McClure, P. J., Kilsby, D., Brown, M. H. \& Coote, P. J. (2000). Germination-induced bioluminescence, a route to determine the inhibitory effect of a combination preservation treatment on bacterial spores. Appl Environ Microbiol 66, 3735-3742.

Driks, A. (1999). The Bacillus subtilis spore coat. Microbiol Mol Biol Rev 63, 1-20.

Driks, A. \& Setlow, P. (1999). Morphogenesis and properties of the bacterial spore. In Prokaryotic Development, pp. 191-218. Edited by Y. V. Brun \& L. J. Shimkets. Washington, DC: American Society for Microbiology.

Fairhead, H., Setlow, B. \& Setlow, P. (1993). Prevention of DNA damage in spores and in vitro by small, acid-soluble proteins from Bacillus species. J Bacteriol 175, 1367-1374.

Flowers, R. S., Martin, S. E. \& Ordal, Z. J. (1977). Catalase and enumeration of stressed Staphylococcus aureus cells. Appl Environ Microbiol 33, 1112-1117.

Gadelha, F. R., Thomson, L., Fagian, M. M., Costa, A. D., Radi, R. \& Vercesi, A. E. (1997). $\mathrm{Ca}^{2+}$-independent permeabilization of the inner mitochondrial membrane by peroxynitrite is mediated by membrane protein thiol cross-linking and lipid peroxidation. Arch Biochem Biophys 345, 243-250.

Gerhardt, P., Scherrer, R. \& Black, S. H. (1972). Molecular sieving by dormant spore structures. In Spores V, pp. 68-74. Edited by H. O. Halvorson, R. Hanson \& L. L. Campbell. Washington, DC: American Society for Microbiology.

Guidi-Rontani, C., Weber-Levy, M., Labruyere, E. \& Mock, M. (1999). Germination of Bacillus anthracis spores within alveolar macrophages. Mol Microbiol 31, 17-19.

Hill, P. J., Hall, L., Vinicombe, D. A., Soper, C. J., Setlow, P., Waites, W. M., Denyer, S. \& Stewart, G. S. A. B. (1994). Bioluminescence and spores as biological indicators of inimical processes. J Appl Bacteriol 76, 129S-134S.

Hood, A. M., Tuck, A. \& Dane, C. R. (1990). A medium for the isolation, enumeration and rapid presumptive identification of injured Clostridium perfringens and Bacillus cereus. J Appl Bacteriol 69, 359-372.

Hozz, N., Darley-Usmar, V. M., Wilson, M. T. \& Moncada, S. (1992). Production of hydroxyl radicals from the simultaneous generation of superoxide and nitric oxide. Biochem $J$ 281, 419-424.

Hurst, J. K. \& Lymar, S. V. (1997). Toxicity of peroxynitrite and related reactive nitrogen species toward Escherichia coli. Chem Res Toxicol 10, 802-810. 
Karp, M. (1989). Expression of bacterial luciferase genes from Vibrio harveyi in Bacillus subtilis and in Escherichia coli. Biochim Biophys Acta 1007, 84-90.

Keyer, K. \& Imlay, J. A. (1997). Inactivation of dehydratase [4Fe$4 \mathrm{~S}]$ clusters and disruption of iron homeostasis upon cell exposure to peroxynitrite. J Biol Chem 272, 27652-27659.

Khairutdinov, R. F., Coddington, J. W. \& Hurst, J. K. (2000). Permeation of phospholipid membranes by peroxynitrite. Biochemistry 39, 14238-14249.

Kuwahara, H., Miyamoto, Y., Akaike, T., Kubota, T., Sawa, T., Okamoto, S. \& Maeda, H. (2000). Helicobacter pylori suppresses bactericidal activity of peroxynitrite via carbon dioxide production. Infect Immun 68, 4378-4383.

Loshon, C. A., Melly, E., Setlow, B. \& Setlow, P. (2001). Analysis of the killing of spores of Bacillus subtilis by a new disinfectant, Sterilox ${ }^{\circledR}$. J Appl Microbiol 91, 1051-1058.

McDonnell, G. \& Russell, A. D. (1999). Antiseptics and disinfectants: activity, action and resistance development. Clin Microbiol Rev 12, 147-179.

Mallozzi, C., Stasi, A. M. \& Minetti, M. (1997). Peroxynitrite modulates tyrosine-dependent signal transduction pathway of human erythrocyte band 3. FASEB J 11, 1281-1290.

Middleton, A. M., Chadwick, M. V., Sanderson, J. \& Gaya, H. (2000). Comparison of a solution of super-oxidized water (Sterilox) with glutaraldehyde for the disinfection of bronchoscopes, contaminated in vivo with Mycobacterium tuberculosis and Mycobacterium avium-intracellulare in sputum. I Hosp Infect 45, 278-282.

Murray, T., Popham, D. L., Pearson, C. B., Hand, A. R. \& Setlow, P. (1998). Analysis of the outgrowth of Bacillus subtilis spores lacking penicillin-binding protein 2a. J Bacteriol 180, 6493-6502.

Nicholson, W. L. \& Setlow, P. (1990). Sporulation, germination and outgrowth. In Molecular Biological Methods for Bacillus, pp. 391-450. Edited by C. R. Harwood \& S. M. Cutting. Chichester: Wiley.

Nicholson, W. L., Munakata, N., Horneck, G., Melosh, H. J. \& Setlow, P. (2000). Resistance of Bacillus endospores to extreme terrestrial and extraterrestrial environments. Microbiol Mol Biol Rev 64, 548-572.

Paidhungat, M. \& Setlow, P. (2001). Spore germination and outgrowth. In Bacillus subtilis and its Relatives: From Genes to Cells. Edited by J. A. Hoch, R. Losick \& A. L. Sonenshein. Washington, DC: American Society for Microbiology.

Paidhungat, M., Setlow, B., Driks, A. \& Setlow, P. (2000). Characterization of spores of Bacillus subtilis which lack dipicolinic acid. J Bacteriol 182, 5505-5512.

Perrin, D. \& Koppenol, W. H. (2000). The quantitative oxidation of methionine to methionine sulfoxide by peroxynitrite. Arch Biochem Biophys 377, 266-272.

Popham, D. L., Helin, J., Costello, C. E. \& Setlow, P. (1996). Muramic lactam in peptidoglycan of Bacillus subtilis spores is required for spore outgrowth but not for spore dehydration or heat resistance. Proc Natl Acad Sci U S A 93, 15405-15410.

Rotman, Y. \& Fields, M. L. (1967). A modified reagent for dipicolinic acid analysis. Anal Biochem 22, 168.
Routledge, M. N. (2000). Mutations induced by reactive nitrogen oxide species in the supF forward mutation assay. Mutat Res $\mathbf{4 5 0}$, 95-105.

Russell, A. D. (1982). The Destruction of Bacterial Spores, pp. 62-64. London: Academic Press.

Russell, A. D. (1990). Bacterial spores and chemical sporicidal agents. Clin Microbiol Rev 3, 99-119.

Selkon, J. B., Babb, R. B. \& Morris, R. (1999). Evaluation of the antimicrobial activity of a new super-oxidized water, Sterilox ${ }^{\mathbb{R}}$, for the disinfection of endoscopes. J Hosp Infect 41, 59-70.

Setlow, B. \& Setlow, P. (1980). Measurements of the $\mathrm{pH}$ within dormant and germinated bacterial spores. Proc Natl Acad Sci US A 77, 2474-2476.

Setlow, B. \& Setlow, P. (1996). Role of DNA repair in Bacillus subtilis spore resistance. J Bacteriol 178, 3486-3495.

Setlow, B., McGinnis, K. A., Ragkousi, K. \& Setlow, P. (2000). Effects of major spore-specific DNA binding proteins on Bacillus subtilis sporulation and spore properties. J Bacteriol 182, 6906-6912.

Setlow, B., Melly, E. \& Setlow, P. (2001). Properties of spores of Bacillus subtilis blocked at an intermediate stage in spore germination. J Bacteriol 183, 4894-4899.

Setlow, P. (1994). Mechanisms which contribute to the long-term survival of spores of Bacillus species. J Appl Bacteriol 23, 49S-60S.

Setlow, P. (2000). Resistance of bacterial spores. In Bacterial Stress Responses, pp. 217-230. Edited by G. Storz \& R. HenggeAronis. Washington, DC: American Society for Microbiology.

Shetty, N., Srinivasan, S., Holton, J. \& Ridgway, C. L. (1999). Evaluation of microbiocidal activity of a new disinfectant: Sterilox ${ }^{\circledR} 2500$ against Clostridium difficile spores, Helicobacter pylori, vancomycin resistant Enterococcus species, Candida albicans and several mycobacterial species. J Hosp Infect 41, 101-105.

Soszynski, M. \& Bartosz, G. (1996). Effect of peroxynitrite on erythrocytes. Biochim Biophys Acta 1291, 107-114.

Spek, E. J., Wright, T. L., Stitt, H. S., Taghizadeh, N. R., Tannenbaum, S. R., Marinus, M. G. \& Engelward, B. P. (2001). Recombinational repair is critical for survival of Escherichia coli exposed to nitric oxide. J Bacteriol 183, 131-138.

Tennen, R., Setlow, B., Davis, K. L., Loshon, C. A. \& Setlow, P. (2000). Mechanisms of killing of spores of Bacillus subtilis by iodine, glutaraldehyde and nitrous acid. J Appl Microbiol 89, 330-338.

Williams, N. D. \& Russell, A. D. (1993a). Revival of biocide-treated spores of Bacillus subtilis. J Appl Bacteriol 75, 69-75.

Williams, N. D. \& Russell, A. D. (1993b). Revival of Bacillus subtilis spores from biocide-induced injury in the germination process. J Appl Bacteriol 75, 76-81.

Yasbin, R. E., Cheo, D. \& Bol, D. (1993). DNA repair systems. In Bacillus subtilis and Other Gram Positive Bacteria: Biochemistry, Physiology and Molecular Genetics, pp. 529-538. Edited by A. L. Sonenshein, J. A. Hoch \& R. Losick. Washington, DC: American Society for Microbiology.

Received 18 June 2001; revised 7 September 2001; accepted 24 September 2001. 